\title{
Analisis Swot Sebagai Landasan Dalam Menentukan Strategi Pemasaran Pada Rameyza Tour \& Travel Bondowoso
}

\author{
Dwi Andri Risqianto ${ }^{1}$, Imam Suroso ${ }^{2}$, Ridwan Iskandar ${ }^{3}$ \\ STIE Mandala Jember ${ }^{1}$, Universitas Jember ${ }^{2}$, Politeknik Negeri Jember ${ }^{3}$
}

\begin{abstract}
This study aims to determine alternative marketing strategies and their implications for marketing Rameyza Tour \& Travel Branch Bondowoso. Analytical method used is SWOT analysis. Internal factor analysis (IFAS) and external factors (EFAS) are used to determine the firm's position through the quadrant table. IE Metrics and SWOT Metrics are used to determine marketing strategic formulations that are appropriate to current corporate conditions. The results showed that Rameyza Tour \& Travel Bondowoso Branch is in quadrant $V$, this means marketing strategy that must be done is horizontal innovation strategy that is in applying its strategy focused on the addition or improvement to the implementation of the function of each activity in the business unit of Tour \& Travel service. In the description of SWOT metrics, there are several alternative marketing strategies such as: 1) Improving partnership with institutions and schools, 2) Increasing online promotion to expand market, 3) Promoting promotion especially service for private tour and attracting foreign tourists. 4) Maintaining continuous service quality, 5) Expanding the market by adding products sold, such as aircraft ticketing service, and railways as a productdiversified form.
\end{abstract}

Keywords: SWOT, Marketing, Strategies

\section{PENDAHULUAN}

Pariwisata telah menjadi salah satu industry di dunia dan merupakan andalan utama dalam menghasilkan devisa di berbagai negara. Di Indonesia, kepariwisataan dituntut untuk mampu mengadaptasikan diri terhadap perkembangan yang akan terjadi pada skala nasional, regional, dan internasional baik yang menyangkut aspek-aspek sosial budaya,

Corresponding Author:

Email : rameyzatour88@gmail.com 
pertahanan dan keamanan (Hankam), maupun ilmu pengetahuan dan teknologi (Iptek). Keberhasilan pembangunan kepariwisataan Indonesia ditentukan oleh paling tidak tiga pilar utama yaitu keberhasilan dalam pengembangan produk, keberhasilan dalam pemasaran, dan keberhasilan menciptakan sumber daya manusia termasuk masyarakat pariwisata.

Pariwisata merupakan salah satu faktor ekonomi utama Indonesia yang terus berkembang setiap tahunnya. Indonesia memiliki beberapa daerah wisata yang menjadi andalan untuk dalam industry pariwisata, salah satunya Provinsi Bali. Bali merupakan salah satu daerah tujuan wisata dunia yang banyak digemari oleh para wisatawan baik lokal maupun mancanegara, dengan berbagai potensi yang mampu memikat para wisatawan seperti keindahan alam, keunikan budaya, dan kehidupan sosial masyarakat. Pulau Bali yang total luasnya hanya 5.632,86 kilometer persegi atau hanya 0,29 persen dari luas keseluruhan Indonesia, memiliki potensi andalan yang dikenal dengan sebutan $3 \mathrm{~S}$ yaitu : Sun, Sand, and Sea. Bali banyak mendapat julukan, diantaranya surga terakhir (The Last Paradise) atau surga para wisatawan (Tourist Paradise). Kunjungan wisatawan asing dan domestik mencapai rata-rata 2,5 juta per tahunnya, sehingga Bali dianugerahi penghargaan oleh TIME Asia, sebagai The Most Favourite Destination in The World 2002. (Kompas).

Industri pariwisata merupakan tulang punggung pembangunan perekonomian nasional, dan menjadi andalan Daerah dalam mengisi Pendapatan Asli Daerah (PAD). Tingginya angka wisatawan yang datang ke daerah menarik banyak investor baik lokal maupun asing untuk menginvestasikan dananya dibidang pariwisata termasuk biro perjalanan, perhotelan dan restouran. Untuk mendukung upaya pengembangan dalam industry pariwisata, maka diperlukan pengembangan pula pada sektor turunanya seperti perhotelan, rumah makan dan Biro perjalanan atau Tour and Travel.

Rameyza Tour \& Travel Bondowoso merupakan salah satu perusahaan yang bergerak dalam bidang biro perjalanan. Wilayah bondowoso yang berdekatan dengan Provinsi Bali merupakan sebuah keuntungan bagi Rameyza 
Tour \& Travel Bondowoso untuk memanfaatkan peluang dalam industry pariwisata antara lain sebagai penyedia jasa layanan tour and travel bagi wisatawan, selain itu Bondowoso juga memiliki beberapa potensi wisata salah satunya Kawah Ijen yang cukup terkenal dengan bluefire-nya. Potensi ini bisa dimanfaatkan oleh Rameyza Tour \& Travel Bondowoso sebagai penyedia layanan tour and travel yang unggul. Mengingat banyaknya peluang yang ada disektor pariwisata, Rameyza Tour \& Travel Bondowoso memiliki rencana untuk melakukan pengembangan dan perluasan pangsa pasar yang dimiliki. Untuk mengetahui keberhasilan usahanya dimasa yang akan datang serta mengetahui dimana sebetulnya posisi perusahaan saat ini, perlu dialakukan sebuah analisis terhadap aspek-aspek yang berperan penting dalam pengambilan keputusan pembuatan strategi pemasaran, baik aspek internal maupun eksternal perusahaan.

Menurut Philip kotler (1984) Pemasaran adalah suatu proses dimana individu dan kelompok mendapatkan apa yang mereka butuhkan dan inginkan dengan menciptakan dan mempertukarkan produk dan nilai dengan individu dan kelompok lainnya. Sedangkan Menurut Wiliam J Stanton (1994) mengemukakan pemasaran dalam arti yang luas dan cenderung memandang pengertian pemasaran dri segi aktifitas bisnis nya. Pada dasarnya pemasaran merupakan suatu system keseluruhan dari kegiatan usaha yang ditujukan untuk merencanakan, menemukan harga, mempromosikan dan mendistribusikan barang dan jasa yang dapat memuaskan kebutuhan kepada pembeli yang ada maupun pembeli yang potensial.

Dalam upaya meningkatkan keberhasailan kegiatan pemasaran perlu disusun strategi-strategi pemasaran yang berdasarkan aspek internal seperti kekuatan dan kelemahan yang dimiliki oleh perusahaan dan dikombinasikan dengan aspek eksternal meliputi tersedianya peluang di pasar dan antisipasi terhadap ancaman yang datang dari pesaing. Melihat fenomena dan berbagai literatur yang telah dijelaskan diatas, maka peneliti perlu untuk melakukan kajian yang berkaitan dengan penyusunan strategi pemasaran dengan Judul Analisis SWOT Sebagai Landasan Dalam Menentukan Strategi Pemasaran Pada Rameyza Tour \& Travel Bondowoso. Penelitian ini bertujuan untuk mengetahui kekuatan, 
kelemahan peluang dan ancaman yang dimiliki oleh Rameyza Tour \& Travel Bondowoso. Selain itu penelitian ini bertujuan untuk mengetahui strategi pemasaran dan implikasinya terhadap pemasaran Rameyza Tour \& Travel Cabang Bondowoso

\section{TINJAUAN PUSTAKA}

Menurut Peter Drucker, "Pemasaran adalah hal yang sangat mendasar, sehingga tidak dapat dianggap sebagai fungsi tersendiri. Pemasaran adalah cara memandang seluruh perusahaan dari hasil akhir, yaitu dari pandangannya. Keberhasilan suatu bisnis bukan ditentukan oleh produsen melainkan oleh pelanggannya." Philip Kotler, "Pemasaran adalah suatu proses organisasi dan managerial dimana individu dan kelompok mendapatkan kebutuhan dan keinginan mereka dengan menciptakan, menawarkan dan bertukar sesuatu yang bernilai satu sama lain."

Lingkungan Eksternal Tujuan dari audit eksternal (David,2006:104) adalah untuk mengembangkan daftar yang terbatas tentang peluang yang dapat memberi manfaat dan ancaman yang harus dihindari. Seperti dijelaskan oleh istilah terbatas, audit eksternal tidak ditujukan untuk mengembangkan daftar yang sangat panjang tentang semua faktor yang mungkin mempengaruhi suatu bisnis; sebaliknya, ia ditujukan untuk mengidentifikasi variabel kunci yang menawarkan respon yang dapat dijalankan. Perusahaan harus dapat merespon secara agresif terhadap faktor-faktor tersebut dengan memformulasikan strategi yang mengambil keuntungan dari peluang eksternal atau yang meminimalkan pengaruh dari ancaman potensial. Kekuatan Eksternal (external forces) dapat dibagi menjadi lima kategori besar: (1) kekuatan ekonomi; (2) kekuatan sosial,budaya,demografi, dan lingkungan; (3) kekuatan politik,pemerintah, dan hukum; (4) kekuatan teknologi; dan (5) kekuatan kompetitif. (David,2006: 105)

Semua organisasi memiliki kekuatan dan kelemahan dalam area fungsional bisnis. Tidak ada perusahaan yang sama kuatnya atau lemahnya dalam semua area. Kekuatan dan kelemahan internal, digabungkan dengan peluang dan ancaman eksternal dan pernyataan misi yang jelas, menjadi dasar untuk penetapan 
tujuan strategi. Tujuan dan strategi ditetapkan dengan maksud memanfaatkan kekuatan internal dan mengatasi kelemahan. (David,2006: 158). Proses menjalankan audit internal sangatlah seiring dengan proses menjalankan audit eksternal. Perwakilan manajer dan karyawan dari seluruh perusahaan perlu dilibatkan dalam penentuan kekuatan dan kelemahan perusahaan. Audit internal membutuhkan pengumpulan dan pengasimilasian infornasi tentang operasi manajemen, pemasaran, keuangan/ akutansi, produksi/ operasi, penelitian dan pengembangan-litbang (research and development atau R\&D). dan sistem informasi manajemen perusahaan. Sehingga kekuatan dan kelemahan perusahaan yang paling penting dapat ditentukan secara kolektif. (David,2006: 159)

\section{Strategi Pemasaran}

Strategi pemasaran merupakan pernyataan (baik secara implisit maupun eksplisit) mengenai bagaimana hubungan suatu merek atau lini produk mencapai tujuannya (Bennett, 1998). Sementara itu, Tull dan Kahle (1990) mendefinisikan strategi pemasaran merupakan sebagai alat fundamental yang direncanakan untuk mencapai tujuan perusahaan dengan mengembangkan keunggulan bersaing yang berkesinambungan melalui pasar yang dimasuki dan program pemasaran yang digunakan untuk melayani pasar sasaran tersebut. Pada dasarnya strategi pemasaran memberikan arah dalam kaitannya dengan variable-variable seperti segmentasi pasar, identifikasi pasar sasaran, positioning, dan elemen bauran pemasaran. Strategi merupakan bagian integral dari strategi bisnis yang memberikan arah pada semua fungsi manajemen suatu organisasi.

Perubahan-perubahan yang terjadi pada kondisi eksternal adalah sumber peluang dan ancaman bagi organisasi saat ini maupun periode mendatang. Kondisi eksternal meliputi kejadian dan hal-hal yang tidak dapat secara langsung dikendalikan oleh organisasi. Organisasi hanya mampu mengikuti, mengantisipasi perubahan yang terjadi dengan melihat dan memprediksi trend yang ditunjuknya. Selain itu perubahan juga bisa terjadi dari kondisi internal. Terdapat lima aspek penting yang harus diperhatikan dalam lingkungan internal ini antara lain Aspek organisasi, Aspek personal, Aspek pemasaran, Aspek produksi, dan Aspek 
keuangan. Para pakar menekankan bahwa salah satu instrumen analisis yang dapat digunakan untuk mengatasi perubahan yang terjadi baik dilingkungan eksternal maupun internal organisasi ialah analisis SWOT. Analisis SWOT merupakan suatu metoda untuk merumuskan dan menerapkan trategi perusahaan untuk mencapai misi dan tujuannya. Analisis SWOT dilakukan karena suatu organisasi terlibat dalam berbagai keadaan lingkungan yang dinamis sehingga pengaruh lingkungan terhadap keberhasilan perusahaan sangat dominan.

\section{METODE PENELITIAN}

\section{Rancangan Penelitian}

Metode yang digunakan dalam penelitian ini adalah metode deskriptif yaitu sebagai prosedur pemecahan masalah yang diselidiki dengan menggambarkan atau melukiskan obyek penelitian pada saat sekarang, berdasarkan fakta-fakta yang tampak atau sebagaimana adanya. Metode deskriptif memusatkan perhatiannya pada penemuan fakta-fakta sebagaimana keadaan sebenarnya (Dajan, 2007:19). Dalam penelitian ini sumber informasi yang didapat berasal dari PT Rameyza Tour \& Travel Bondowoso. Dengan alat analisis yang digunakan yaitu analisis SWOT (Strength, Weaknes, Opportunitiy, Threat). Pada penelitian ini jumlah responden yang akan diambil adalah sebanyak 35 responden. Jumlah sampel diatas merupakan gabungan dari sampel eksternal dan internal. Teknik pengambilan sampel memakai Pusposive Sampling yaitu sampel yang dilakukan atas dasar kriteria-kriteria (Arikunto 2006:139). Kriteria sampel yang dipakai dalam penelitian ini dari sisi eksternal adalah masyarakat yang pernah memakai jasa Rameyza Tour \& Travel Bondowoso minimal 1 kali. Dari sisi internal adalah karyawan PT Rameyza Tour \& Travel Bondowoso.

\section{Definisi Operasional Variabel}

Definisi operasional variabel dimaksudkan untuk mengetahui variabel apa saja yang digunakan dalam penelitian ini, antara lain:

1. Strategi Pemasaran, yaitu rencana yang disatukan secara menyeluruh dan terpadu yang mengaitkan strategi pemasaran perusahaan dengan tantangan lingkungan dapat dicapai melalui pelaksanaan strategi pemasaran. 
2. Kekuatan (Strenght) adalah kondisi inernal perusahaan dalam hal ini PT Rameyza Tour \& Travel Bondowoso. Merupakan keunggulan perusahaan dalam menghadapi persaingan. Indikatornya adalah: Memiliki kemitraan dengan berbagai instansi, Lokasi yang strategis, Memiliki daerah pemasaran yang luas, Memiliki fasilitas dan peralatan yang memadai, Permodalan yang memadai

3. Kelemahan (Weaknes) adalah kondisi internal perusahaan yang tidak menguntungkan bagi PT Rameyza Tour \& Travel Bondowoso, dimana kelemahan merupakan kekurangan perusahaan ini. Indikatornya adalah: Ketepatan jadwal berangkat atau datang, Kurangnya promosi yang dilakukan, Kurangnya tenaga pemasar, Belum memiliki alat transportasi milik perusahaan, Harga yang ditawarkan masih relatif tinggi dibandingkan dengan pesaig.

4. Peluang (Opportunitiy) adalah kondisi eksternal perusahaan dalam hal ini PT Rameyza Tour \& Travel Bondowoso yang mendukung atau menguntungkan perusahaan. Kondisi eksternal perusahaan meliputi pengembangan kualitas kerja. Indikatornya adalah: Potensi wisata, Peluang pemasaran secara online, Adanya wisatawan Asing yang ingin melihat Potensi wisata kabupaten Bondowoso, Banyaknya permintaan terhadap layyanan private tour. Layanan pemebelian tiket pesawat dan kereta merupakan peluang untuk differensiasi.

5. Ancaman (Threath) adalah faktor eksternal perusahaan yang dapat merugikan pihak PT Rameyza Tour \& Travel Bondowoso. Kondisi eksternal perusahaan ini meliputi munculnya usaha sejenis. Indikatornya adalah:Munculnya pesaing dengan usaha sejenis, Banyaknya penjual perantara yang meminta fee besar, sehingga mengurangi keuntungan perusahaan, Adanya image negatif dari biro jalanan yang tidak professional, sehigga merusak image baik bagi bisnis travel, Beraneka ragamnya layanan tour \& travel yang dutawarkan oleh pesaing, Adanya pendatang baru yang masuk dengan segmen yang sama 


\section{Metode Analisis Data}

Adapun metode analisis dalam penelitian ini adalah menggunakan SWOT dengan langkah-langkah sebagai berikut:

1. Mengklasifikasi Faktor Strategis Perusahaan

Faktor-faktor strategis perusahaan tediri dari dua (2) faktor, yaitu faktor strategis internal yang memiliki 2 variabel yaitu variabel kekuatan dan kelemahan, dan faktor strategis eksternal yang terdiri dari 2 variabel, yaitu variabel peluang dan ancaman. Identifikasi faktor internal meliputi: Aspek Sumber Daya Manusia, Aspek Operasional, Aspek Pemasaran dan Aspek Keuangan. Sedangkan identifikasi faktor eksternal meliputi: Kondisi Lingkungan Makro (politik, sosial, ekonomi, keamanan, budaya, masyarakat dan kebijakan pemerintah) dan Kondisi Lingkungan Mikro (pesaing dan pangsa pasar).

2. Analisis Deskriptif

Analisis ini dimaksudkan untuk mengetahui distribusi frekuensi jawaban responden dari daftar pertanyaan / kuesioner yang disebarkan dan berisikan variabel kekuatan, kelemahan, peluang dan ancaman. Setelah mengetahui frekuensi jawaban responden baru dapat diberikan penilaian terhadap masingmasing indikator variabel kekuatan, kelemahan, peluang, ancaman.

Menentukan Matrik IFAS (Internal Strategic Analysis Summary) dan EFAS (Eksternal Strategic Analysis Summary)

Penentuan metriks IFAS bertujuan untuk memperkirakan faktor-faktor yang berkaitan dengan lingkungan internal dengan mengidentifikasi berbagai macam kemungkinan kekuatan dan kelemahan yang terangkum dalam suatu tabel yang kemudian diberi bobot untuk menentukan seberapa jauh peran dan fungsinya. Sedangka EFAS bertujuan untuk memperkirakan faktor-faktor yang berkaitan dengan lingkungan eksternal (peluang dan ancaman).

\section{Menentukan Posisi Perusahaan}

Pemberian bobot dan rating yang diringkas dalam kolom IFAS untuk faktor internal serta EFAS untuk faktor eksternal selanjutnya dipakai dalam 
menentukan posisi perusahaan dengan menggunakan Internal External Matrik yang disingkat IE Matrik. Tujuan penggunaan model ini adalah untuk memperoleh strategi bisnis tingkat korporat yang lebih detail (Rangkuti,2006:42). IE Matrik mempunyai 9 (Sembilan kolom) yang terdiri dari 3 besaran output dasar yaitu strategi pertumbuhan, stabilitas dan penghapusan/ divestasi.

\section{Menentukan Alternatif Strategi Pemasaran pada Perusahaan}

Analisis data yang dilakukan berdasarkan atas matrik IFAS dan EFAS diatas yaitu matrik yang menggambarkan kondisi internal dan eksternal. Proses penganalisisan melalui tahapan matrik SWOT. Pada matrik ini menggambarkan kekuatan dan kelemahan secara bersama-sama dipadukan dengan peluang serta ancaman sehingga secara umum hakekat SWOT adalah berusaha secara bersama-sama memaksimalkan kekuatan dan peluang dengan meminimalkan ancaman dan kelemahan. Dalam matrik SWOT output yang dihasilkan terdiri dari empat alternatif strategi yang tergambarkan dalam matrik berikut.

\section{Tabel 1 Matrik SWOT}

\begin{tabular}{|l|l|l|}
\hline \multicolumn{1}{|c|}{ IFAS } & $\begin{array}{l}\text { Strengths (S) } \\
\text { Tentukan 5 samapi 10 faktor } \\
\text { kekuatan internal }\end{array}$ & $\begin{array}{l}\text { Weakness (W) } \\
\text { Tentukan 5 samapi 10 } \\
\text { faktor kekuatan internal }\end{array}$ \\
\hline $\begin{array}{l}\text { Opportunities (O) } \\
\text { Tentukan 5-10 faktor } \\
\text { peluang eksternal }\end{array}$ & $\begin{array}{l}\text { Strategi SO } \\
\text { Strategi yang memanfaatkan } \\
\text { kekuatan untuk memanfaatkan } \\
\text { peluang }\end{array}$ & $\begin{array}{l}\text { Strategi WO } \\
\text { Strategi yang menanfaatkan } \\
\text { peluang } \\
\text { meminimalkan kelemahan }\end{array}$ \\
\hline $\begin{array}{l}\text { Threats (T) } \\
\text { Tentukan 5-10 faktor } \\
\text { ancaman eksternal }\end{array}$ & $\begin{array}{l}\text { Strategi ST ategi ang menggunakan } \\
\text { kekuatan untuk mengatasi } \\
\text { ancaman }\end{array}$ & $\begin{array}{l}\text { Strategi WT } \\
\text { Strategi } \\
\text { meminimalkan kelemahan } \\
\text { dan menghindari ancaman }\end{array}$ \\
\hline Sumber: Rangkuti,2006:31 & \\
\hline
\end{tabular}

\section{HASIL DAN PEMBAHASAN}

\section{Faktor Internal dan Eksternal}

a. Aspek Pemasaran

Untuk meningkatkan penjualan jasa PT Rameyza Tour \& Travel selalu meningkatkan pelayanan kepada konsumennya dengan memberikan 
kenyamanan dan keamanan saat menggunakan jasa yang ditawarkan. Meningkatkan promosi melalui media cetak dan online.

b. Aspek Sumber Daya Manusia.

Karyawan pada PT Rameyza Tour \& Travel dengan pemberian gaji yang diberikan setiap bulannya sesuai dengan posisi dan jabatan. Selain gaji pokok juga ada tunjanagan hari raya. Hubungan personal pada PT Rameyza Tour \& Travel dapat terjalin dengan baik karena adanya pengertian masing-masing pihak pimpinan maupun karyawan. Hal ini dapat di lihat dari keakraban yang nampak pada setiap harinya.

c. Aspek Operasional.

Sebagai perusahaan yang bergerak di bidang jasa yang menawarkan produk paket perjalanan wisata, maka semakin baik kualitas peralatan yang digunakan semakin baik pula kualitas pelayanan jasa yang diberikan. PT Rameyza Tour \& Travel telah memiliki bangunan kantor yang permanen sehingga konsumen tidak terlalu bingung dalam mencari lokasi kantornya. Letak PT Rameyza Tour \& Travel sangat strategi karena berada di lingkungan perkotaan dan di pusat keramaian di pinggir jalan, sehingga sangat mudah dijangkau dengan kendaraan apapun.

d. Aspek Keuangan

Aspek keuangan merupakan aspek yang sensitif bagi kebanyakan perusahaan, begitu pula pada PT Rameyza Tour \& Travel. Oleh karena itu, peneliti tidak dapat menguraikan secara detail dan melampirkan data tentang keuangan biro perjalanan tersebut. Berdasarkan keterangan pihak manajemen PT Rameyza Tour \& Travel keuangan perusahaan tidak pernah mengalami masalah dalam hal pembayaran gaji karyawan, pembayaran listrik, telepon, dan tagihantagihan lain.

\section{Analisis Lingkungan Makro}

Lingkungan Ekonomi

Bondowoso merupakan salah satu kabupaten di Jawa Timur yang letaknya cukup strategis karena berada dipersimpangan antara Surabaya dan Bali, sehingga 
perkembangannya cukup pesat dan menjadi barometer pertumbuhan ekonomi di kawasan timur Jawa Timur. Sebagai daerah otonom, kabupaten Bondowoso memiliki batas-batas teritorial, luas wilayah, kemampuan ekonomi, potensi daerah, sosial politik dan sosial budaya serta sumber daya manusia. Kondisi obyektif yang demikian dapat mengungkapkan berbagai karakterisyik sumber daya alam, komoditas yang dihasilakan, mata pencaharian penduduk, keadaan serta ekonomi dan sosial budayanya yang mencerminkan kekuatan sebagai suatu kompetensi daerah. Di daerah Bondowoso juga terdapat banyak tempat wisata yang bisa dikunjungi, diantaranya Wisata Ijen, Kawah Wurung dan lain-lain.

Lingkungan Pemerintah

Perubahan kondisi politik akan membawa damapak yang sifatnya penting. Dampak terhadap perusahaan biasanya sangat mendasar dan sering kali menentukan kesinambungan suatu perusahaan. dimana keberadaan pemerintah dapat memberikan kesempatan atau peluang yang seluas-luasnya namaun dapat menjadi penghalang bagi perusahaan dalam dunia usaha. Selain membawa kemudahan juga ada kebijakan pemerintah yang berpengaruh terhadap dunia usaha yaitu kebijakan pemerintah yang menaikkan tarif listrik, telepon, BBM, yang berpengaruh langsung terhadap kegiatan operasional P T Rameyza Tour \& Travel Bondowoso.

\section{Analisis Lingkungan Mikro}

Lingkungan Pesaing

Aspek pesaing merupakan aspek lingkungan eksternal yang bisa menjadi ancaman bagi perusahaan, sehingga menimbulkan persaingan yang ketat di antara perusahaan jasa yang sejenis baik dari segi kualitas kerja, keamanan, kenyamanan, keefisienan yang memungkinkan loyalitas konsumen berubahubah. Biro jasa perjalanan yang ada di Bondowoso antar lain Andre Tour, Santosa Tour selain itu pesaing juga datang dari luar Bondowoso seperti dari jember yakni Nuansa Wisata Prima Tour \& Travel, Warna Indonesia Tour \& Travel, Javanica Tour \& Travel, Luna Tour \& Travel, Bunga Tour \& Travel, dll. Menurut ASITA (Association of the Indonesian tour and Travel Agencies) cabang 
Jember, diantara semua biro perjalanan Warna Indonesia Tour \& Travel dan Nuansa Wisata Prima Tour \& Travel. Melihat adanya persaingan yang begitu ketat P T Rameyza Tour \& Travel Bondowoso berusaha untuk meningkatkan daya saing dan kualitas pelayanaan terhadap konsumennya.

Pangsa Pasar

Pangsa pasar yang dibidik oleh PT Rameyza Tour \& Travel Bondowoso yaitu lembaga pendidikan, karena hampir setiap tahun melakukan kunjungan wisata, misalaya : Study Tour, studi banding, dan Rekreasi serta outbond. Kemudian perusahaan-perusahaan serta instansi-instansi pemerintahan yang biasanya pada saat liburan mengadakan acara rekreasi. PT Rameyza Tour \& Travel Bondowoso tidak hanya membidik pasar lokal saja, akan tetapi pasar luar kota seperti kabupaten bontang yang selama ini telah menjadi pelanggannya, selain itu turis mancanegara juga tidak lepas dari bidikan P T Rameyza Tour \& Travel Bondowoso para wisatawan asing ini biasanya berkunjung ke indonesia untuk melakukan long march dalam berlibur, sepertti ke bali, lombok, ijen, bromo dan lain-lain.

Menentukan Matrik IFAS (Internal Strategic Analysis Summary) dan EFAS (Eksternal Strategic Analysis Summary)

Tabel 2. Hasil IFAS (Internal Strategic Analysis Summary)

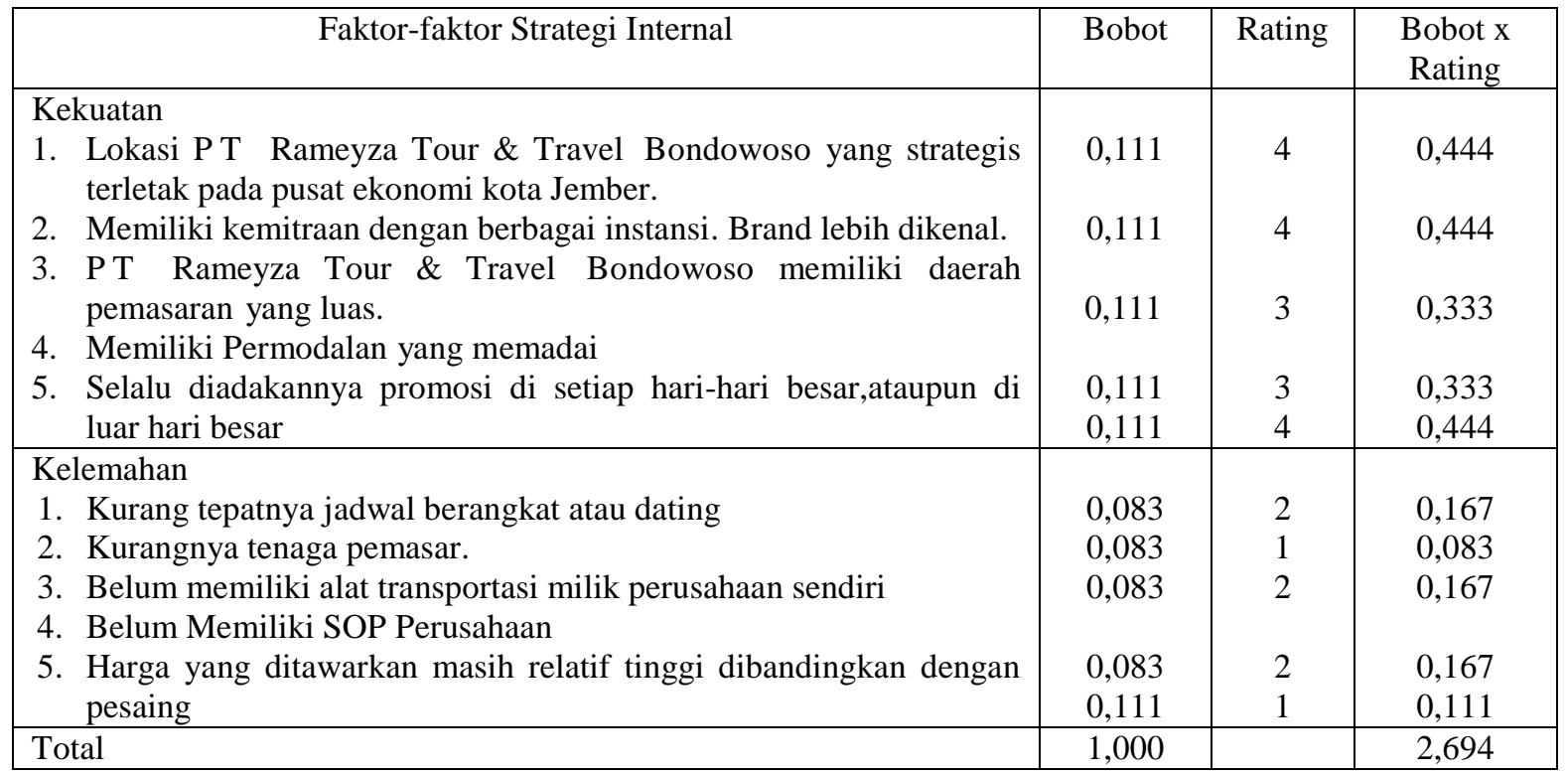


Dari Tabel diatas bisa dilihat kekuatan yang dihasilkan P T Rameyza Tour \& Travel Bondowoso dengan nilai rating rata-rata 4 yang berarti mempunyai nilai positif sangat besar. Hal ini menunjukkan bahwa semua kekuatan yang ditimbulkan bisa digunakan untuk bersaing dengan kompetitor, sedangkan untuk kelemahan rata-rata rating yang diberikan adalah 3 yang berarti memiliki pengaruh negatif kecil sehingga perlu diperhatikan oleh pihak perusahaan.

Tabel 3. Hasil EFAS (Eksternal Strategic Analysis Summary)

\begin{tabular}{|c|c|c|c|}
\hline Faktor-faktor Strategi Eksternal & Bobot & Rating & $\begin{array}{l}\text { Bobot } x \\
\text { Rating }\end{array}$ \\
\hline \multicolumn{4}{|l|}{ Peluang } \\
\hline $\begin{array}{l}\text { 1. Animo masyarakat Bondowoso yang ingin mempunyai } \\
\text { waktu untuk liburan seperti, wisata religi, study tour, sytudi } \\
\text { banding, out bond }\end{array}$ & 0,100 & 4 & 0,400 \\
\hline 2. Peluang pemasaran secara online. & 0,100 & 4 & 0,400 \\
\hline 3. Adanya wisatawan Asing yang ingin melihat Potensi wisata & 0,100 & 4 & 0,400 \\
\hline $\begin{array}{l}\text { kabupaten Bondowoso. } \\
\text { 4. Banyaknya permintaan terhadap layyanan private tour }\end{array}$ & 0,100 & 3 & 0,300 \\
\hline $\begin{array}{l}\text { 5. Layanan pemebelian tiket pesawat dan kereta merupakan } \\
\text { peluang untuk differensiasi. }\end{array}$ & 0,100 & 2 & 0,200 \\
\hline \multicolumn{4}{|l|}{ Ancaman } \\
\hline $\begin{array}{l}\text { 1. Harga layanan tour yang tinggi sehingga daya beli } \\
\text { konsumen menurun }\end{array}$ & 0,100 & 1 & 0,100 \\
\hline $\begin{array}{l}\text { 2. Banyaknya penjual perantara yang meminta fee besar, } \\
\text { sehingga mengurangi keuntungan perusahaan. }\end{array}$ & 0,100 & 2 & 0,200 \\
\hline $\begin{array}{l}\text { 3. Adanya image negatif dari biro jalanan yang tidak } \\
\text { professional, sehigga merusak image baik bagi bisnis } \\
\text { travel. }\end{array}$ & 0,100 & 2 & 0,200 \\
\hline $\begin{array}{l}\text { 4. Beraneka ragamnya layanan tour \& travel yang dutawarkan } \\
\text { oleh pesaing }\end{array}$ & 0,100 & 2 & 0,200 \\
\hline $\begin{array}{l}\text { 5. Adanya pendatang baru yang masuk dengan segmen yang } \\
\text { sama }\end{array}$ & 0,100 & 1 & 0,100 \\
\hline Total & 1,000 & & 2,500 \\
\hline
\end{tabular}

Dari Tabel EFAS bisa dilihat rata-rata rating yang dihasilkan adalah 4 yang berarti memiliki pengaruh positif sangat besar dengan begitu peluang yang dihasilkan P T Rameyza Tour \& Travel Bondowoso bisa dimanfaatkan menjadi kekuatan, sedangkan ancaman yang mempunyai nilai rating rata-rata 2 yang 
berarti memiliki pengaruh negatif besar jadi ancaman yang dihasilkan/ timbul harus benar-benar diperhatikan oleh perusahaan.

\section{Penentuan Posisi Perusahaan.}

Berdasarkan Klasifikasi IFAS pada tabel dan EFAS pada tabel diketahui bahwa skor total untuk faktor-faktor strategis Internal adalah 2,694, sedangkan untuk skor total faktor strategis Eksternal adalah 2,500. Untuk mengetahui gambaran strategis perusahaan berdasarkan formulasi IFAS dan EFAS selanjutnya dierhitungkan dengan matrik Internal Eksternal (IE Matrik) pada gambar berikut :

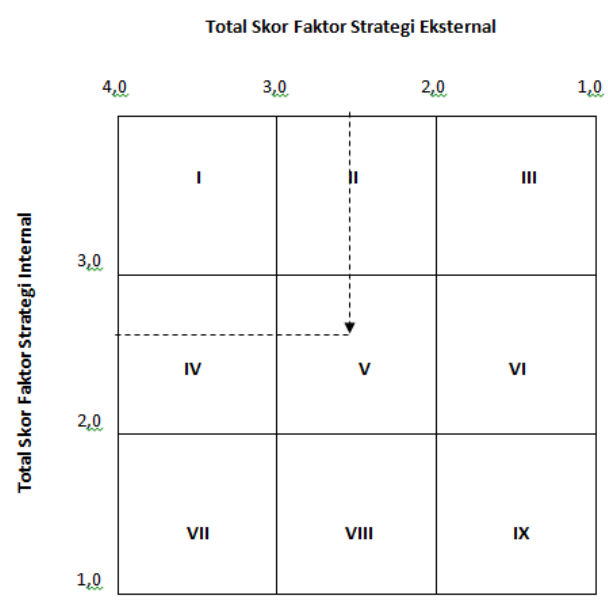

Gambar 1. Metrik Internal Eksternal.

Berdasarkan formulasi IE Matrik, didapatkan posisi gambaran bintang strategi P T Rameyza Tour \& Travel Bondowoso yaitu pada kuadran V (Lima) yang bertanda bintang $(2,694: 2,500)$. Dalam kuadran 5 ini, P T Rameyza Tour \& Travel Bondowoso saharusnya menetapkan strategi konsentrasi melalui integrasi horizontal atau stabilitas. Penerapan strategi ini memberikan arti bahwa:

1. Keputusan strategis utamanya difokuskan pada perbaikan pelaksanaan fungsinya. PT Rameyza Tour \& Travel Bondowoso dalam menerapkan strateginya difokuskan pada penambahan atau perbaikan terhadap pelaksanaan fungsi masing-masing kegiatan dalam unit usaha layanan Tour \& Travel 
2. Menerapkan strategi konsolidasi, tujuannya relatif lebih defensif yaitu menghindari kehilangan layanan tour \& travel dan kehilangan profit, (Rangkuti,2006:45)

\section{Alternatif Strategi Pemasaran Perusahaan disajikan pada Tabel 4 berikut.}

\section{Tabel 4. Alternatif Strategi}

\begin{tabular}{|c|c|c|}
\hline EFAS & $\begin{array}{l}\text { Kekuatan (Strenght) } \\
\text { 1. Lokasi P T Rameyza Tour \& } \\
\text { Travel Bondowoso yang strategis } \\
\text { terletak pada pusat ekonomi kota } \\
\text { Jember. } \\
\text { 2. Memiliki kemitraan dengan } \\
\text { berbagai instansi. Brand lebih } \\
\text { dikenal. } \\
\text { 3. P T Rameyza Tour \& Travel } \\
\text { Bondowoso memiliki daerah } \\
\text { pemasaran yang luas. } \\
\text { 4. Memiliki Permodalan yang } \\
\text { memadai diand } \\
\text { 5. Selalu diadakannya promosi di } \\
\text { setiap hari-hari besar,ataupun di } \\
\text { luar hari besar (disesuaikan dengan } \\
\text { tema yang diambil oleh } \\
\text { perusahaan). }\end{array}$ & $\begin{array}{l}\text { Kelemahan (Weakness) } \\
\text { 1. Kurang tepatnya jadwal } \\
\text { berangkat atau dating } \\
\text { 2. Kurangnya tenaga pemasar. } \\
\text { 3. Belum memiliki alat } \\
\text { transportasi milik perusahaan } \\
\text { sendiri } \\
\text { 4. Belum Memiliki } \\
\text { Perusahaan } \\
\text { 5. Harga yang ditawarkan masih } \\
\text { relatif tinggi dibandingkan } \\
\text { dengan pesaing }\end{array}$ \\
\hline $\begin{array}{l}\text { Peluang (Opportunity) } \\
\text { 1. Animo masyarakat Bondowoso yang } \\
\text { ingin mempunyai waktu untuk } \\
\text { liburan seperti, wisata religi, study } \\
\text { tour, sytudi banding, out bond } \\
\text { 2. Peluang pemasaran secara online. } \\
\text { 3. Adanya wisatawan Asing yang ingin } \\
\text { melihat Potensi wisata kabupaten } \\
\text { Bondowoso. } \\
\text { 4. Banyaknya permintaan terhadap } \\
\text { layanan private tour } \\
\text { 5. Layanan pembelian tiket pesawat dan } \\
\text { kereta merupakan peluang untuk } \\
\text { differensiasi.. }\end{array}$ & $\begin{array}{l}\text { S - O STRATEGY } \\
\text { 1. Meningkatkan hubungan kemitraan } \\
\text { dengan instansi dan sekolah, } \\
\text { (S2,S5,O1) } \\
\text { 2. Meningkatkan promosi secara } \\
\text { online untuk memperluas pasar, } \\
\text { (S1,S5,O1,O2,03) } \\
\text { 3. Meningkatkan Promosi khususnya } \\
\text { layanan untuk private tour dan } \\
\text { menarik wisatawan asing. } \\
\text { (S1,S5,O3,04) } \\
\text { 3.Menjaga kualitas layanan agar } \\
\text { kualitasnya selalu terjaga, hal ini } \\
\text { penting untuk manjaga kepercayaan } \\
\text { masyarakat dan meningkatkan image } \\
\text { yang baik di mata masyarakat. } \\
\text { (S5,S4,01) } \\
\text { 5.Memperluas pasar dengan menambah } \\
\text { produk yang dijual, seperti layanan } \\
\text { pebelian tiket Pesawat, dan kereta api } \\
\text { sebagai bentuk difersifikasi produk. } \\
\text { (S5,05) }\end{array}$ & $\begin{array}{l}\text { W - O STRATEGY } \\
\text { 1. Mengembangkan kualitas SDM } \\
\text { dengan pemberian pelatihan } \\
\text { kerja pada karyawan. } \\
\text { (W1,W4,O1,O2) } \\
\text { 2. Melakukan penghematan } \\
\text { anggaran untuk merencanakan } \\
\text { pembeliat alat transportasi } \\
\text { (W3,O1,O4) } \\
\text { 3. Mengadakan perekrutan untuk } \\
\text { memenuhi layanan permintaan } \\
\text { (W2,O1,O5) } \\
\text { 4. Melakukan efisiensi kegiatan } \\
\text { operasional untuk menekan } \\
\text { tingginya harga pokok } \\
\text { penjualann (W5,O1,O2) }\end{array}$ \\
\hline
\end{tabular}




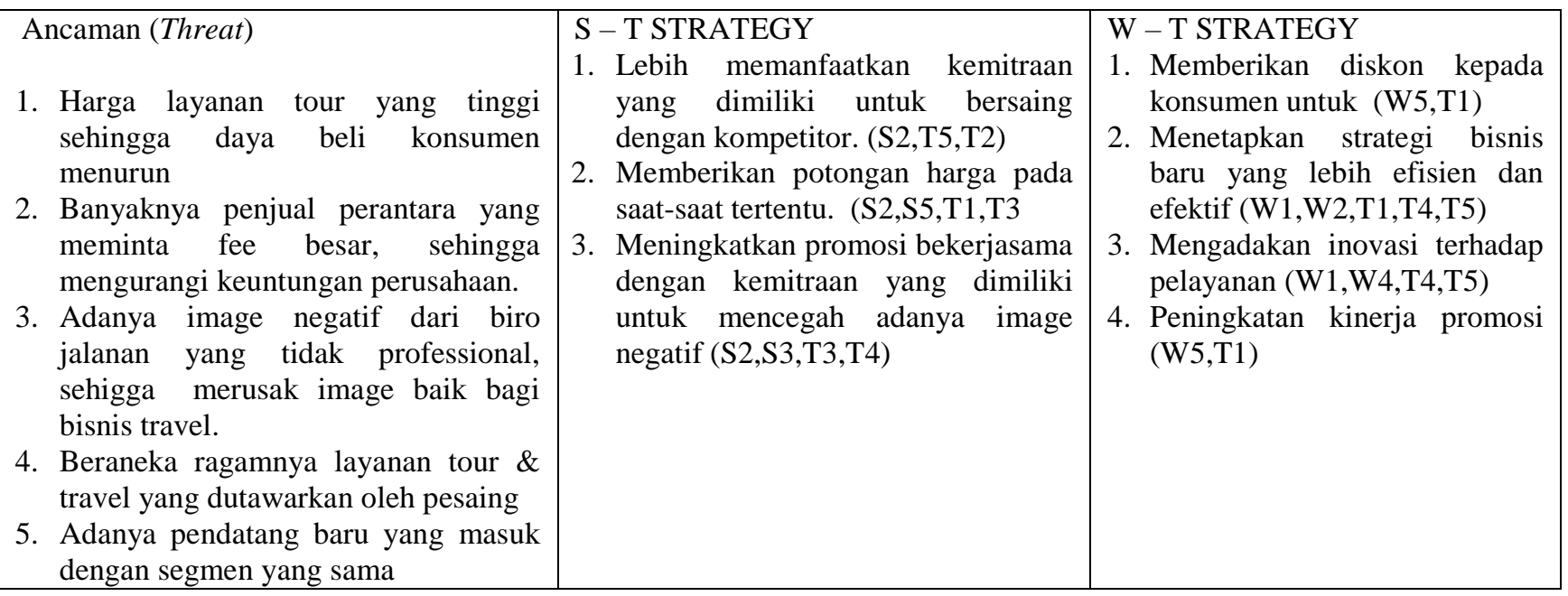

Berdasarkan hasil formulasi matrik SWOT pada Tabel 4.3 di atas, maka didapat alternatif pemasaran yang dapat diterapkan pada perusahaan PT Rameyza Tour \& Travel Bondowoso dalam memanfaatkan kekuatan dan peluang untuk mengatasi kelemahan dan ancaman. Alternatif strategi tersebut adalah

\section{Strategi S-O (Strenght - Opportunity)}

a. Meningkatkan hubungan kemitraan dengan instansi dan sekolah

Peningkatan hubungan kemitraan bertujuan untuk melayani animo masyarakat Bondowoso yang ingin mempunyai waktu untuk liburan seperti, wisata religi, study tour, sytudi banding, out bond. Hal ini disebabkan kegiatan tour semacam ini banyak dilakukan oleh instansiinstansi dan sekolah. Adanya jalinan kerjasama ini akan memberikan dampak positif bagi perusahaan untuk bisa mempertahankan konsumen karena lebih sulit dalam mempertahankan konsumen daripada mencari konsumen baru.

b. Meningkatkan promosi secara online untuk memperluas pasar.

Meningkatkan pangsa pasar yang ada untuk produk-produk tertentu melalui usaha pemasaran. Pengembangan pasar melibatkan perkenalan variasi layanan tour \& travel yang ada saat ini ke area geografi yang baru. Pada umumnya strategi ini dilakukan apabila perusahaan sangat berhasil dalam apa yang dilakukan, perusahaan memiliki kelebihan kapasitas produk, ataupun karena adanya pasar yang belum tersentuh atau belum januh 
(David,2006:234)

c. Meningkatkan Promosi khususnya layanan untuk private tour dan menarik wisatawan asing.

Strategi ini bertujuan untuk melayni permintaan private tour dan wisatawan asing, pada umumnya wisatawan asing ini berkunjung ke Indonesia dalam rangka long march vacation. Untuk memanfaatkan peluang ini perusahaan hendaknya memberikan layanan 1 paket layanan tour untuk wistawan asing.

d. Menjaga kualitas layanan agar kualitasnya selalu terjaga, hal ini penting untuk manjaga kepercayaan masyarakat dan meningkatkan image yang baik di mata masyarakat.

e. Memperluas pasar dengan menambah produk yang dijual, seperti layanan pebelian tiket Pesawat, dan kereta api sebagai bentuk difersifikasi produk.

Strategi ini bertujuan untuk mendapatkan peluang keuntungan selain kegiatan usaha utamnya, dengan cara melayani pembelian tiket pesawat dan KA serta kemungkinan layanan lainnya akan memberikan keunggulan dan differensiasi layanan dibandingkan dengan jenis usaha tour \& travel yang lainnya.

\section{Strategi W-O (Weakness - Opportunity)}

a. Mengembangkan kualitas SDM dengan pemberian pelatihan kerja pada karyawan.

Strategi ini bertujuan untuk mengantisipasi adanya ancaman dari pesaing yang memiliki kualitas SDM lebih handal. Selain itu strategi ini juga efektif untuk meningkatkan kualitas layanan perusahaan dalam memenuhi permintaan yang muncul dari animo masyarakat bondowoso.

b. Melakukan penghematan anggaran untuk merencanakan pembelian alat transportasi.

Hal ini bertujuan untuk meminimalisir biaya akibat pengadaan sewa alat transportasi, jika perusahaan memiliki sendiri alat transportasi maka kemungkinan besar perusahaan dapat memberikan harga yang relatif lebih rendah karena adanya efisiensi terhadap biaya operasional. 
c. Mengadakan perekrutan untuk memenuhi layanan permintaan.

Strategi ini bertujuan untuk memenuhi layanan yang notabene semakin meningkat setiap harinya.

d. Melakukan efisiensi kegiatan operasional untuk menekan tingginya harga pokok penjualan.

Strategi ini bertujuan untuk menghadapi masalah yang sering kali terjadi, yakni harga pada Rameyza tour and travel relatif lebih tinggi dibandingkan dengan pesaing, sehingga konsumen memilih biro perjalanan yang lainnya. Dengan melakukan efisiensi terhadap biaya operasional diharapkan mampu membuat harga pokok penjualan yang relatif lebih rendah dan dapat bersaing di pasar.

\section{Strategi S-T (Strength - Threat)}

a. Lebih memanfaatkan kemitraan yang dimiliki untuk bersaing dengan kompetitor.

Hal ini bisa dialkukan dengan cara menjaga hubungan baik dengan pemegang kepemimpinan dalam instansi dan sekolah, karena pada umumnya keputusan penggunaan layanan biro perjalanan ditentukan oleh pihak pimpinan. Hal ini bertujuan untuk lebih memudahkan dalam mendapatkan pelanggan.

b. Memberikan potongan harga pada saat-saat tertentu.

Strategi ini bertujuan untuk menghadapi pesaing yang memiliki program tour \& travel lebih rendah dibandingkan PT Rameyza Tour \& Travel Bondowoso. Sehingga dapat mempertahankan kepuasan pelanggan yang selama ini menggunakan layanan jasa PT Rameyza Tour \& Travel Bondowoso.

c. Meningkatkan promosi dengan bekerjasama kemitraan yang dimiliki untuk mencegah adanya image negatif.

Mitra yang sudah puas terhadap layanan yang diberikan tidak akan mudah berpindah terhadap biro perjalanan lainnya.

\section{Strategi W-O (Weakness - Threat)}


a. Memberikan diskon kepada konsumen untuk kategori produk kebutuhan sehari-hari. Strategi ini bertujuan untuk mengatasi permasalahan Harga layanan tour yang diberikan masih relatif tinggi sehingga daya beli konsumen menurun. Dengan adanya diskon diharapkan dapat mengimbangi pola permainan harga yang dimiliki oleh pesaing.

b. Menetapkan strategi bisnis baru yang lebih efisien dan efektif. Yaitu untuk menarik minat konsumen agar konsumen tertarik menggunakan jasa yang ditawarkan karena adanya inovasi baru seperti pemberian diskon, paket harga khusus, dll

c. Mengadakan inovasi terhadap pelayanan (W1,W4,T4,T5). Dengan melakukan pengembangan usaha, perusahaan akan memiliki daerah pemasaran yang luas agar mampu bersaing dengan perusahaan yang jenis usahanya sama, seperti membuka cabang baru

d. Peningkatan kinerja promosi (W5,T1). Peningkatan promosi penjualan perlu dilakukan bagi perusahaan agar konsumen banyak yang semakin tahu tentang produk jasa yang ditawarkan dan dengan promosi penjualan yang efektif akan mampu menarik minat konsumen yang lebih banyak.

\section{Strategi Pemasaran}

Dari hasil pilihan alternatif strategi perusahaan yang telah diperoleh peneliti dan pihak perusahaan berdiskusi untuk menentukan strategi pemasaran pada perusahaan P T Rameyza Tour \& Travel Bondowoso yang benar-benar sesuai dengan situasi dan kondisi serta tujuan perusahaan P T Rameyza Tour \& Travel Bondowoso Dari hasil diskusi antara peneliti dan pihak perusahaan didapatkan strategi pemasaran sebagai berikut:

\section{Meningkatkan Pangsa Pasar}

Dilihat dari banyaknya obyek wisata yang potensial dijember, maka yang harus dilakukan oleh P T Rameyza Tour \& Travel Bondowoso adalah dengan meningkatkan pangsa pasar. Pengembangan pasar melibatkan perkenalan layanan yang ada saat ini ke area geografi yang baru. Tujuan dari strategi ini adalah memperkenalkan atau memperluas usaha yang sudah ada ke daerah pemasaran 
yang baru agar pangsa pasar bertambah. Fokus dari strategi ini adalah membuka jaringan pemasaran baru di tempat lain atau memasang tenaga kerja freeline yang bergunan untuk melayani permintaan, meningkatkan kepercayaan dan kepuasan konsumen P T Rameyza Tour \& Travel Bondowoso dari luar daerah.

\section{Meningkatkan mutu pelayanan konsumen.}

Pelayanan merupakan faktor terpenting dalam meningkatkan kepuasan konsumen. Strategi ini dimunculkan karena saat ini pesaing juga meningkatkan mutu pelayanannya melalui beragam program layanan tour, harga yang relatif lebih rendah dan jaringan pemasaran yang lebih luas, sehingga P T Rameyza Tour \& Travel Bondowoso juga harus memberikan pelayanan yang tidak kalah saing dengan biro pperjalanan lainnya. Fokus dari strategi ini adalah Penambahan program layanan baru yang sebelumnya belum pernah ada atau layanan tour yang sedang banyak dicari konsumen, meningkatkan jumlah variasi layanan seperti paket tour, private tour dan berbagai program layanan tour yang mungkin bisa dijalankan sesuai dengan kebutuhan pasar. Dengan adanya varian program yang ditawarkan ini maka kepuasan konsumen akan dapat lebih ditingkatkan, karena seringkali terjadi pelanggan menjadi kecewa karena layanan yang di berikan tidak sesuai dengan harapan pelanggan.

\section{Menciptakan differensiasi}

Strategi Differensiasi menawarkan berbagai tingkat differensiasi. Differensiasi tidak menjamin keunggulan kompetitif, khususnya jika produk standart cukup untuk memenuhi kebutuhan konsumen atau imitasi cepat dapat dilakukan pesaing. Pada prinsipnya strategi ini adalah mengambil pelanggan sebagai titik perhatian utama. Strategi ini menitik beratkan pada membangun persepsi pembeli akan keunggulan kualitas, desain produk, teknologi, jaringan distribusi,image,berat, bahan, dan pelayanan. Perusahaan dapat menetapkan harga tinggi akan tetapi harus bisa menciptakan produk bagi konsumen tampak berbeda (lebih unggul) ketimbang produk lain yang sudah ada sehingga tampak unik (different). Strategi differensiasi harus dijalankan setelah proses belajar yang berhati-hati tentang kebutuhan dan preferensi pembeli untuk menentukan kelayakan dari penggunaan 
satu fitur yang membedakan atau lebih ke dalam suatu produk yang unik yang menampilkan atribut yang diinginkan (David,2006:248) Fokus dari strategi ini adalah:

a. PT Rameyza Tour \& Travel Bondowoso harus lebih memantapkan pada peningkatan layanan baru yang memiliki relevansi dengan jenis usaha traveling. Seperti penjualan tiket, adanya paket khusus, untuk private tour dan wisatawan asing. Program-program ini harus bersinergi dengan satu sama lain dan di dukung dengan pengembangan sumber daya manusia melalui pelatihan, pendidikan agar mereka mampu melayani konsumen dengan baik.

b. Dengan berbagai macam kekuatan yang dimiliki, seperti program kemitraan yang selama ini berjalan baik dengan instansi dan sekolah juga harus ditingkatkan untuk memanfaatkan peluang yang ada, layanan permintaan yang berasal dari kemitraan ini harus sedapat mungkin memuaskan konsumennya, hal ini bertujuan uuntuk menjaga hubungan jangka panjang degan kemitraan dan menciptakan image yang baik dimata masyarakat sekaligus enjadi pembeda dengan biro perjalanan lainya.

\section{Melakukan promosi yang efektif dan tepat sasaran}

Dalam hal promosi yang dilakukan oleh PT Rameyza Tour \& Travel Bondowoso memang tidak terlalu gencar, maka dari strategi ini mutlak dilakukan karena perusahaan paling lemah didalam hal promosi. Peningkatan promosi penjualan perlu dilakukan bagi perusahaan agar konsumen banyak yang semakin tahu tentang produk jasa yang ditawarkan dan dengan promosi penjualan yang efektif akan mampu menarik minat konsumen yang lebih banyak. Upaya yang dilakukan adalah melalui media cetak, elektronik, event dan lain-lain. Misal sebagai sponsor utama dalam kegiatan-kegiatan yang dilakukan oleh instansi maupun sekolah-sekolah dan perguruan tinggi. Serta pada kegiatan masyarakat yang memilki potensi untuk menggunakan jasa PT Rameyza Tour \& Travel Bondowoso misal adanya kemungkinan masyarakat yang akan mengadakan wisata religi. 
Selain itu kegiatan promosi juga harus dilakukan secara online. Hal ini untuk memenuhi permintaan yang datangnya dari wisatawan mancanegara yang ingin berkunjung di berbagai tempat wisata di Indonesia seperti Bali, Lombok, Ijen, dan bromo. Tempat-tempat wisata ini bisa dijadikan program paket wisata dengan harag yang relatif terjangkau, program paket wisata ini juga harus bekerja sama dengan pihak perhotelan dan semacamnya untuk kemudahan wisatawan dalam mendapatkan fasilitas penginapan yang dikelola secara langsung oleh P T Rameyza Tour \& Travel Bondowoso.

\section{KESIMPULAN}

Posisi perusahaan dalam penelitian ini adalah terdapat pada kuadran v. Dalam kuadran 5 ini, PT Rameyza Tour \& Travel Bondowoso saharusnya menetapkan strategi konsentrasi melalui integrasi horizontal atau stabilitas. Fokus strategi harus mengarah pada penambahan atau perbaikan terhadap pelaksanaan fungsi masing-masing kegiatan dalam unit usaha layanan Tour \& Travel dan Menerapkan strategi konsolidasi untuk menghindari kehilangan layanan tour \& travel dan kehilangan profit.

P T Rameyza Tour \& Travel Bondowoso hendaknya dapat memanfaat potensi wisata-wisata yang berada di Jember, untuk menarik para wisatawan yang berasal dari dalam maupun luar Bondowoso untuk meningkatkan pangsa pasar. Selain itu perusahaan juga perlu meningkatkan kualitas pelayanan jasa agar tidak timbul keluhan-keluhan dari konsumen dan mengembangkan kualitas SDM agar dapat memenuhi permintaan yang ada seperti kebutuhan layanan terhadap wisatawan asing, sehinggan sehingga hal ini akan meningkatkan omset penjualan.

\section{DAFTAR PUSTAKA}

Amaretta, Melinda and Evelyn Hendriana. 2011. "The Effect of Marketing Communications and Price Promotion to Brand Equity", The $2^{\text {nd }}$ International Research Symposium in Service Management. Yogyakarta, Indonesia, hal. 26-30. 
Asauri, Sofyan. (1997), Manajemen Pemasaran: Dasar,Konsep dan Startegi CV Rajawali, Jakarta.

Cutlip, Scott M. Allen H. Center \& Glen M. Broom. 2006. Effective Public Relations. New Jersey: Prentice Hall.

Danibrata, Aulia. 2011. Pengaruh Integrated Marketing Communication terhadap Brand Equity pada sebuah Bank Pemerintah di Jakarta. Jurnal Bisnis dan Akuntansi, 13(1): 21-38.

Fill, Chris. 2009. Marketing Communication : Interactivity, Communities, and Content 5th ed. New Jersey: Prentice Hall.

Josep Porte Guiltinan and Gordon Paul (1992). Startegi dan Program Manajemen Pemasaran Alih Bahasa Oleh Agus Maulana, Edisi kedua Erlangga, Jakarta.

Jouch, R. Lawrence. William F. Glueeck. 2004. Manajemen Startegi dan Kebijakan Perusahaan ,Edisi ketiga. Jakarta: Erlangga.

Kotler P \& G. Armstrong. 2008. Prinsip- Prinsip Pemasaran. Terjemah oleh Bob Sabran, M.M. Edisi 12. Jilid 2. Jakarta: Erlangga.

Kotler, Philip \& Keller, Kevin Lane. 2009, Manajemen Pemasaran. Terjemah oleh Bob Sabran, M.M. Edisi 13. Jilid 2. Jakarta: Erlangga.

Kotler, Philip. John Bown dan James Makens. 2002. Pemasaran Perhotelan dan Kepariwisataan. Terjemah oleh Alexander Sindoro dan Renata Pohan. Edisi 2. Jakarta: PT. Prenhallindo.

Machin, David \& Michael J. Champbell.1987. Satistical Table for The Design of Clinical Trial. Oxford London: Blackwell Scientific Publication.

Nazir, Moh. 2009. Metode Penelitian. Cetakan Ketujuh. Bogor: Ghalia Indonesia.

Prasesty, Dwi, A. Yulia. 2005. Penentuan Strategi Pemasaran Berdasarkan analisis SWOT Paada pandu logistik cabang jember, Skripsi, FE Universitas Jember.

Rangkuti, Fredy. 2006. Analisis SWOT: Teknik Membedah Kasus Bisnis Dan Analisa Kasus Cetakan kedua belas Jakarta: PT.Gramedia Pustaka Utama.

Uma, Sekaran. 2006. Metodelogi Penelitian Untuk Bisnis. Jilid 2 Edisi 4. Jakarta: Salemba Empat. 